\title{
„Ale właściwie dlaczego zawsze miałoby się dziać tak, jakeśmy do tego przywykli?". Reprezentacja zmian klimatu w serii o Muminkach Tove Jansson W perspektywie studiów nad jedzeniem
}

\section{Abstrakt:}

Celem artykułu jest analiza sposobu, w jaki w serii o Muminkach (1945-1970) Tove Jansson przedstawia zmiany klimatu zachodzące w fikcyjnym świecie, zarówno za pośrednictwem scen katastroficznych, jak i tych sugerujących długofalowy proces. Autor tekstu dowodzi, że motyw zmieniającej się ilości, jakości i różnorodności dostępnego jedzenia staje się „językiem”, który pozwala opowiedzieć o zjawisku spoza codziennego doświadczenia postaci. Losy rodziny zostają dzięki temu umieszczone w szerszym kontekście, a to, co niesamowite, autorka przedstawia za pomocą zwyczajów związanych z żywnością, stanowiących jedną z ważniejszych kwestii w życiu Muminków. Jansson, wykorzystując także formę sagi rodzinnej, pokazuje, w jaki sposób można stworzyć narrację o zmianach klimatu, która omawia sam proces, a nie jego skutki.

Słowa kluczowe:

ekokrytyka, literatura dziecięca i młodzieżowa, Muminki, studia nad jedzeniem, Tove Jansson, zmiana klimatu

"But why should everything be exactly as one is used to having it?": Representation of Climate Change in the Moomin Series by Tove Jansson in View of Food Studies

\section{Abstract:}

The aim of this article is to speculate on how in her Moomin series (1945-1970)

Tove Jansson presents the climate change occurring in her fictional world through

* Michał Czajkowski - mgr, przygotowuje rozprawę doktorską w Szkole Doktorskiej Nauk Humanistycznych na Uniwersytecie Warszawskim dotyczącą komiksu dziecięcego i młodzieżowego. Pracuje w Muzeum Książki Dziecięcej (dziale specjalnym Biblioteki Publicznej m.st. Warszawy - Biblioteki Głównej Województwa Mazowieckiego). Kontakt: mhczajkowski@gmail.com. 
the catastrophic scenes and those suggesting that a more long-term process is involved in shaping the narrative. The author of the paper argues that the amount, quality, and diversity of available food become a "language" which allows talking about the phenomenon from beyond the characters' everyday experience. The family's fates are thus positioned in a wider context, and the uncunny is shown through nutrition habits, which perform an important role in Moomins' lives. Jansson using a family saga form shows how the narration about climate change as a process, not particular events, can be created.

Key words:

ecocriticism, children's and young adult literature, Moomins, food studies, Tove Jansson, climate change

\section{Wprowadzenie}

$\mathbf{Z}$ miany klimatu zachodzące w Dolinie Muminków i jej okolicach na przestrzeni kilku lat wpływają na życie postaci w bardzo znaczący sposób, mimo że niemal żadna z nich tego nie zauważa. Szczęśliwa kraina dobrobytu zmienia się z czasem w świat, którego integralną częścią staje się niedobór żywności, dzieje się to jednak tak wolno z perspektywy postaci, że staje się niemożliwe do opowiedzenia. W serii Tove Jansson, czytanej przez pryzmat food studies oraz studiów nad kryzysem klimatycznym, można dostrzec niemożliwość znalezienia słów dla czegoś, co nie zamyka się w ramach czasowych wyznaczanych przez pojedyncze wydarzenia, jak powódź czy przelot komety, ale jest zjawiskiem większym, obejmującym wspomniane katastrofy. David Wallace-Wells (2019) zwraca uwagę, że stworzenie narracji na temat zmian klimatu staje się niemożliwe, kiedy nie można się wobec nich zdystansować, a zjawisko dotyka kogoś bezpośrednio i w czasie rzeczywistym kształtuje jego sposób funkcjonowania w świecie:

Można opowiadać „o” zmianie klimatu, gdy ta wydaje się jakąś marginalną cechą ludzkiego życia lub osią życia ludzi niemających dla nas znaczenia. [...] w miarę jak zmiana klimatu zagarnia cały horyzont i zaczyna wydawać się nieuchronna, całkowita, z opowieści może zamienić się we wszechobecny kontekst. $\mathrm{W}$ to, co teoretycy literatury określają mianem metanarracji w rodzaju tych, jakie panowały w epokach wcześniejszych: prawdy religijnej czy wiary w postęp (s. 171-172).

W świecie Muminków niemożność opowiedzenia o zmianach wynika jednak z silnego napięcia między ich skalą a codziennością złożoną z rytuałów 
mających zapewnić poczucie bezpieczeństwa i kontroli nad własnym losem. Opowieść o życiu rodziny i jej znajomych staje się poszukiwaniem języka, który pozwoliłby zrozumieć niesamowite (z perspektywy małych istot) wydarzenia. Doświadczenia tak trudne jak przymusowa migracja ${ }^{6}$ wywołana zagrożeniem życia, głód czy brak w pełni bezpiecznego i stałego schronienia domagają się tymczasem zrozumienia. Mieszkańcy i mieszkanki fikcyjnego świata $\mathrm{z}$ wieloma $\mathrm{z}$ tych zjawisk stykają się po raz pierwszy w życiu, podobnie jak czytelnik i czytelniczka - w tym przypadku opis nie powinien wywoływać nadmiernego obciążenia psychicznego w myśl zasady wyznawanej przez samą Jansson (1978), którą Jolanta Ługowska (2012, s. 451) zawiera w sformułowaniu primum non nocere.

Niniejszy artykuł ma na celu zbadanie, w jaki sposób losy Muminków kształtowane są przez relację środowiska naturalnego z zamieszkującymi je istotami. Zarówno przedstawienie historii Muminków jako sagi, jak i zmieniające się w ramach jej poszczególnych części ilość i jakość żywności w okresach katastrofy i dobrobytu pozwalają umiejscowić długofalowe zjawisko w kontekście codziennego życia jednostki. Z analizy wyłączam tom Pamiętniki Tatusia Muminka (Jansson, 1950/2018), jako że opowiedziane w nim losy tytułowej postaci nie należą do tej samej linii czasowej co pozostałe tomy (stanowią retrospekcję), do których odwołuję się w tekście. Opieram się głównie na koncepcji ciągłości i nieciągłości narracji klimatycznych zaproponowanej przez Amitava Ghosha (2016) w tekście The Great Derangement: Climate Change and the Unthinkable.

\section{Jak przedstawić niewyobrażalne?}

Przedstawienie tego, co niewyobrażalne, wymaga zupełnie innego rodzaju narracji niż ta dążąca do racjonalizowania świata, czynienia go jak najbardziej realistycznym, skupiona na wydarzeniach, ich przyczynach i konsekwencjach, a nie na samym procesie. Robert Macfarlane (2005) stwierdza, że kryzys

6 Migracja wydaje mi się najlepszym określeniem tego, co spotyka m.in. leśne istoty w tomie Zima Muminków. Karolina Ćwiek-Rogalska (2013, s. 34) w kontekście wymuszonych wędrówek postaci w całej serii stosuje określenie „przesiedlenie”, rozumiane jako częściowo dobrowolne opuszczenie dotychczasowego miejsca zamieszkania, ale termin ten zakłada intencjonalne działanie zewnętrznej siły (np. politycznej), która staje się przyczyną opuszczenia dotychczasowego miejsca - wojna czy przymusowe przesiedlenia to efekty planowania, które wywołują chaos w życiu jednostki. Tymczasem Muminki i inne istoty z Doliny i okolic nigdy nie zmieniają miejsca zamieszkania z własnej woli, zostają do tego zmuszone przez siły natury lub konsekwencje ich działania. 
klimatyczny istnieje głównie w „niewidzialnej literaturze”7 (przytacza to określenie za J. G. Ballardem), czyli we wszelkiego rodzaju opracowaniach takich jak raporty czy czasopisma, ale nie w beletrystyce. Tymczasem, jak zauważa, dzięki fabularyzacji opowieści o zmianach klimatu możliwe jest dyskutowanie ich przyczyn i skutków w przestrzeni „widzialnej”, czyli, przez analogię, dostępnej także niespecjalistom i odbiorcom nieposiadającym przygotowania do analizy danych naukowych; doświadczanie hipotetycznych sytuacji tak, jakby były prawdziwe, pozwala połączyć teraźniejsze działanie z przyszłymi konsekwencjami. Wymaga to jednak środków, które pozwalają przedstawić zmianę zachodzącą w długim okresie. Choć autorowi prawdopodobnie chodziło o powieści mniej metaforyczne i osadzone stricte w rzeczywistości jak najbardziej zbliżonej do tej, w której żyją czytelnicy i czytelniczki (mam na myśli m.in. nurt climate fiction, poruszający tematykę wpływu cywilizacji człowieka na środowisko i próbujący przewidzieć, w jaki sposób może wyglądać ukształtowana przezeń przyszłość), serię o Muminkach można odczytać jako obraz kryzysu klimatycznego obejmujący czas dłuższy niż jedno wydarzenie. Wykorzystanie formy sagi do ukazania owego kryzysu pozwala przedstawić zmianę zachodzącą powoli, ponieważ u fundamentów tej formy leży założenie, że akcja rozgrywa się w ciągu wielu lat, umożliwiając zaprezentowanie losów jednej rodziny. Jej dzieje nie muszą koniecznie wiązać się z wielopokoleniowością; może to być historia zarówno jednej osoby czy jednego pokolenia, jak i wielu. Opowieść Jansson przedstawia zmianę, która zmusza rodzinę Muminków do nieustannego godzenia dotychczasowego trybu życia z nowymi warunkami, co w całej serii urasta do rangi sztuki życia (Gralewicz-Wolny, 2019, s. 109).

Dzięki temu zabiegowi Jansson udaje się uniknąć jednego z najpoważniejszych problemów związanych z literacką reprezentacją zmian klimatu - założenia, że tylko człowiek może celowo wywierać wpływ na otoczenie i doświadczać konsekwencji podejmowanych decyzji (Ghosh, 2016, s. 31). Samo posiadanie świadomości sprawia, że w mniejszym lub większym stopniu można kontrolować środowisko lub dostosowywać się do niego na podstawie pozyskanych informacji. Synonimami zmian klimatu, postrzeganych jako element antropocentrycznego układu odniesienia, stają się zatem możliwe do zaobserwowania katastrofy, których przyczyny można wskazać z mniejszą lub większą dokładnością. Zyskuje się w ten sposób iluzję niemal nieograniczonych możliwości człowieka w świecie mu podporządkowanym: ludzie z jednej strony dysponują potencjałem do niszczenia środowiska, $z$ drugiej - do naprawiania

\footnotetext{
Jeśli nie podano inaczej, wszystkie tłumaczenia autora artykułu - Michała Czajkowskiego.
} 
własnych błędów i przywracania równowagi. Ekosystem w tym ujęciu staje się bierny, poddany istocie, która wywołuje pożar, ale i go gasi; konsekwencją jej działań staje się huragan, co wpływa na rozwój systemu wczesnego ostrzegania; doprowadza do powodzi, ale potem uczy się budować lepsze wały przeciwpowodziowe. Zmiany w mentalności zachodzące pod wpływem procesów zewnętrznych są zatem łatwe do wskazania.

Tymczasem w przypadku serii Jansson mamy do czynienia $\mathrm{z}$ apologią tego procesu, na który mieszkańcy i mieszkanki świata podlegającego przeobrażeniom nie mają wpływu, oraz akceptacji jego oddziaływania na codzienne życie. Aleksandra Maria Korczak (2016) określa to zjawisko mianem „apoteozy życia jako misterium przemiany" (s. 88), jej stwierdzenie wymaga jednak uzupełnienia. Autorka odnosi się jedynie do zachodzących w fikcyjnym świecie transformacji o charakterze cyklicznym (a zatem obiecujących poprawę, która nadejdzie po trudniejszym czasie), a konkretnie do następstwa pór roku, które wpływa na funkcjonowanie Muminków i ich sąsiadów - czego najwyraźniejszym przykładem jest wielomiesięczny zimowy sen, zwyczaj niepodlegający refleksji jako coś funkcjonującego od niepamiętnych czasów.

Istoty zamieszkujące fikcyjny świat Jansson dostosowują się jednak nie tylko do zmian przewidywalnych, lecz także tych o charakterze katastrofy, pojawiających się niespodziewanie, o czym piszę w dalszej części tekstu na przykładzie przebudzenia po wyjątkowo srogiej zimie. Najlepiej podsumowuje to Mama Muminka pytaniem, które stało się częścią tytułu niniejszego artykułu, a które pada w chwili, kiedy w Lecie Muminków powódź zalewa Dolinę i odwraca porządek świata, zmuszając do zmiany przyzwyczajeń (Jansson 1954/2017b, s. 39). To nie władza nad otoczeniem i możliwość jego dostosowania do własnych potrzeb staje się oznaką siły i przystosowania się do środowiska, lecz umiejętność zaufania prostym czynnościom i gestom będącym źródłem sensu w sytuacji, w której nic nie zależy od naszej woli (Ługowska, 2012, s. 455).

Skupianie się na najbardziej bieżących sprawach, „robienie swojego”, wydaje się najwyżej wartościowaną w świecie Muminków postawą wobec zmiany klimatu, daje bowiem największe szanse na przetrwanie. Ten sposób na przedstawienie roli kryzysu w życiu istot tak małych jak trolle łatwo może stać się przeszkodą w próbie ukazania znaczenia tak długofalowego zjawiska. Rozbijanie większej, bardziej złożonej narracji - w tym przypadku opowieści o zmianach klimatu w skali globalnej - na mniejsze, łatwiejsze do pojęcia epizody Ghosh (2016, s. 56) określa mianem myślenia przez tworzenie nieciągłości. Podejście to zakłada, że rozwiązaniem skomplikowanego problemu może być suma rozwiązań składających się na niego zagadnień. Tymczasem przenoszenie tego sposobu myślenia na kwestie zmian klimatu staje się o tyle 
ryzykowne, że skupianie się na bieżących trudnościach może stać się celem samym w sobie, ważniejszym niż dotarcie do ich źródła. Między innymi dlatego w serii o istotach poświęcających uwagę przede wszystkim temu, co tu i teraz, postacie myślące bardziej abstrakcyjnie przedstawia się jako dziwadła oderwane od rzeczywistości (naukowcy z obserwatorium $w$ Komecie nad Dolina Muminków; Jansson, 1968/2016), ignoruje się je (Homek z Lata Muminków; Jansson 1954/2017b) lub ukazuje jako doprowadzające w swojej refleksji do przerostu formy nad treścią (Migotek i jego zamiłowanie do wszelkiego rodzaju ceremoniałów). Ukształtowanie przekazu zgodnie z zasadą tworzenia mikronarracji, mających pozwolić odbiorcy pobieżnie rozeznać się w kontekście, jedynie utwierdza w przekonaniu, że zmiana klimatu to zespół spektakularnych wydarzeń.

Jednocześnie wiele czynników sprawia, że trudno wyobrazić sobie, iż wszystkie zjawiska wokół nas są ze sobą powiązane. $Z$ tego powodu stają się niemal nieprzedstawialne w literaturze. Największymi przeszkodami wydają się:

- Skala - fakt, że coś dzieje się we wszystkich miejscach jednocześnie i w bardzo długim przedziale czasu, obejmującym nawet dziesięciolecia, sprawia, że zjawisko przestaje być wydarzeniem, a staje się kontekstem (McKibben, 2005). Zmiana dostrzegalna jest przez kontrast między chwilą obecną a przeszłą, na tyle oddaloną w czasie, że wyraźnie widać różnicę; sam proces umyka zaś uwadze, jeśli nie śledzimy go na bieżąco.

- Spektakularność - uwagę mocniej przykuwają wydarzenia nagłe, w wyrazisty sposób burzące dotychczasowy porządek, niż procesy powoli zmieniające otoczenie i sposób naszego życia. $\operatorname{Korczak}(2016$, s. 86) zauważa, że rzeczywistość Muminków kształtują właśnie małe apokalipsy, które wpływają na dalsze życie postaci; z kolei Iwona Gralewicz-Wolny (2019, s. 107) zwraca uwagę na to, że powódź to „opowieść” nie tyle o wodzie, ile o spotkaniu wody z lądem, a zatem o samym momencie przekroczenia granicy między jedną przestrzenią a drugą, niosącym zniszczenie i chaos. Macfarlane (2005) ujmuje spektakularność w ten sposób: „Apokalipsa przychodzi nagle i charyzmatycznie, a zmiana klimatu narasta dyskretnie". Kiedy dochodzi do katastrofy, to ona przykuwa niemal całą uwagę, niewiele miejsca pozostawiając próbom wyjaśnienia jej przyczyny, jako że najpilniejsze wydaje się szybkie reagowanie na aktualne wydarzenia.

- Niesamowitość - zmian klimatu nie da się ująć w ramy narracji opartej na nieciągłościach, trudno bowiem za pomocą podziału na epizody opowiedzieć o doświadczeniu, którego istotą jest pewne kontinuum, ścisłe 
powiązanie danego elementu ze wszystkimi innymi zjawiskami. W tym ujęciu człowiek nie jest jedynie czynnikiem sprawczym, biernym obserwatorem czy ofiarą „złego losu”, ale wchodzi ze środowiskiem w relację określaną przez Ghosha (2016, s. 32) mianem intymnej - konsekwencje wyborów powracają do osoby działającej, kwestionując zasadność dotychczasowego sposobu postrzegania świata. Proces staje się jednak nieopisywalny, jako że podważa granice kategorii stosowanych do zrozumienia rzeczywistości, ujawnia prawdziwą skalę wydarzeń ingerujących w codzienne życie. Niczego nie da się już zamknąć w opowieść, ponieważ jedno zjawisko wiedze ku kolejnemu, sprawiając, że wszystko zaczyna zdawać się groteskowe, nieuchwytne, przytłaczające. Nieciągła narracja przestaje wystarczać w świecie kształtowanym przez ciągłość, a te same doświadczenia łączą ze sobą różne miejsca i mogą być postrzegane w zupełnie odmienny sposób (s. 62). W serii o Muminkach dochodzi wręcz do animizacji zjawiska czy żywiołu, przypisania mu woli i intencjonalności, ponieważ, w duchu stwierdzenia Jansson (1978, s. 9), że najgorszy jest strach bez nazwy, można powiedzieć, że łatwiej uwierzyć w żywą istotę (nieważne jak wielką czy obcą), z którą można się zmierzyć, niż w nieożywione zjawisko. Widać to chociażby w scenie, w której Tata Muminka stara się przemówić do rozsądku wzburzonemu morzu, zawstydzić je i wskazać właściwy sposób postępowania wobec wyspy (Jansson 1965/2014, s. 220-221).

- Poza-ludzkość - katastrofy wywołane przez zmiany klimatu podważają postrzeganie ludzkich możliwości jako nieograniczonych, uświadamiają istnienie sił, których nie da się ujarzmić. Już nie tylko sposób postrzegania świata przez człowieka wpływa na interpretowanie przezeń przestrzeni; zjawiska poza-ludzkie stają się o wiele silniejszymi czynnikami kształtującymi potrzeby i dążenia, zyskują bezpośredni wpływ na jego umysł (Ghosh, 2016, s. 31). Zdają się nie podlegać prawom i zasadom, które ludzie starają się narzucić wszystkim istotom dzielącym $\mathrm{z}$ nimi ekosystem. Działają według niepoznanych w pełni reguł i stanowią przejawy zjawiska o wiele większego, wymykającego się całościowemu zrozumieniu przez swoją złożoność.

\section{Małe trolle i wielki świat}

Narracja w serii o Muminkach kształtowana jest z perspektywy istoty rozmiaru trolla, trudno zatem wskazać, które dokładnie wydarzenia mają wpływ na stabilność klimatu fikcyjnego uniwersum. Dolina Muminków reprezentuje 
cały poznany świat, a przynajmniej centrum wyznaczające granice oddziaływania kulturowego; to, co dzieje się poza nimi, jest nieistotne, ponieważ nie należy do rzeczywistości istot, których oczy zwracają się nieustannie ku rodzinie i swojemu miejscu zamieszkania ${ }^{8}$. Przelot komety w tomie Kometa nad Dolina Muminków oraz wybuch wulkanu w Lecie Muminków można jednak uznać za przyczyny coraz większego ochłodzenia. Obie katastrofy wystarczą, żeby rozpocząć przeobrażenia przypominające te zachodzące w rzeczywistości pozatekstowej podczas małej epoki lodowcowej, kiedy ochłodzenie klimatu często wiązane ze zwiększoną ilością pyłu w atmosferze - następowało fazami od 1300 roku (Lanchester, 2019). Ograniczenie ilości promieni słonecznych docierających do powierzchni Ziemi miało być jedną z głównych przyczyn zmiany, która zaczęła się w okresie największej aktywności wulkanicznej od czasu antyku (w latach 1250-1500) i pogłębiła w wyniku kilku wyjątkowo silnych erupcji (w latach 1560-1800). Długotrwałe skutki tych wydarzeń wiązały się z zaburzeniami równowagi pogodowej i klimatycznej, skróceniem okresu wegetacji roślin oraz nieregularnościami opadów deszczu (Behringer, 2007/2010, s. 87-93). Nie zawsze zaś, wbrew nazwie tego okresu, musiało dochodzić do zlodowacenia - skutkiem wybuchu indonezyjskiego wulkanu Tambora miały być zarówno spadek ilości światła słonecznego, jak i wyjątkowo ciepłe lata w okresie po erupcji (Mann, 2002, s. 508).

To, że przelot komety i wybuch „góry ziejącej ogniem” w świecie Muminków wpłynęły na skład atmosfery, zostaje powiedziane wprost - w Komecie nad Doliną Muminków cały ogród Mamy zostaje pokryty pyłem (Jansson 1968/2016, s. 26-28), w Lecie Muminków natomiast Włóczykij obserwuje wyjątkowo spektakularne zachody słońca (Jansson 1954/2017b, s. 81). Opóźniony czas zakwitania roślin i skrajne temperatury stają się m.in. przyczyną głodu, który powoduje napływ mieszkańców z okolicy do Doliny w Zimie Muminków (Jansson, 1957/2017e) - wyjątkowo ostra zima jest wydarzeniem bezprecedensowym,

8 Jednym z dowodów na to, że dolina stanowi kulturowe i duchowe axis mundi świata Jansson, jest tom Dolina Muminków w listopadzie (1970/2017a), w którym postacie, dotarłszy do istotnych momentów w życiu (najczęściej kryzysowych), ciągną ku domowi rodzinnemu, żeby znaleźć rozwiązania dręczących je problemów. Jednocześnie trudno mówić w tej części serii o jakiejkolwiek konkretnej przestrzeni, jako że ci, którzy nadawali jej znaczenie, są nieobecni. Mapy dołączane do kolejnych tomów pokazywały, że to obecność rodziny Muminków w określonym otoczeniu wyznaczała granice między orbis interior i orbis exterior (Pessel, 2019, s. 56), ale w tej części mapa ukazuje świat z perspektywy ogólnej, nie wyróżniając żadnego elementu - wszystko stało się tak samo ważne lub tak samo nieważne (s. 59). 
jako że zapasy i strategie przetrwania mieszkańców i mieszkanek lasu okazują się niewystarczające:

Był to ogromnie ważny dzień. Również i z tej przyczyny, że po południu pojawił się obcy przybysz.

Był nim mały, chudy pies w naciągniętej na oczy dziurawej, wełnianej czapce. Twierdził, że nazywa się Ynk i że zapasy żywności w dalej położonych dolinach skończyły się już dawno. Od czasu, kiedy przyszła Lodowa Pani, jeszcze trudniej znaleźć coś do jedzenia [...]. W każdym razie liczne rzesze były w drodze do Doliny Muminków (s. 79-80).

Wspomnianą scenę od przejścia Lodowej Pani dzieli kilka dni, więc zgromadzona żywność, zgodnie z relacją Ynka, musiała skończyć się na długo przed jej przybyciem. Istoty mieszkające w lesie trudno byłoby posądzić o lekkomyślność, jako że zima przychodzi każdego roku; najbardziej prawdopodobnym wyjaśnieniem głodu, który dotyka tak wiele z nich, jest niedostatek żywności w okresie tworzenia zapasów oraz mrozy większe niż dotychczas, wymagające dostarczania większej liczby kalorii. Nawet w spiżarni Muminków, wypełnionej jedynie konfiturami, panuje mniejsza różnorodność, niż można by się spodziewać, co także wskazuje na potencjalne kłopoty z takim gospodarowaniem żywnością, żeby jej część zabezpieczyć na zimę, a przy tym nie odczuwać mniejszej ilości jedzenia na co dzień. Opisane w Zimie Muminków wydarzenia mogły zatem być efektem nieprzewidywalności pogody - a istoty przyzwyczajone do stabilnego klimatu nie umiały się należycie przygotować na jej konsekwencje.

Nie tylko tak spektakularne wydarzenia uznać można za konsekwencję długofalowych zmian klimatu w świecie Jansson. Postępujące ochłodzenie wpływa także, choć mniej zauważalnie, na zwyczaje Muminków, które - niejako podświadomie - zaczynają odczuwać nadchodzący czas coraz większego nieurodzaju. Widać to chociażby w Historii o ostatnim smoku na świecie z tomu Opowiadania z Doliny Muminków (Jansson, 1962/2017d, s. 64-81), w której Muminek sięga po szufladę z zapasami znajdującą się w jego pokoju, żeby nakarmić tytułowe zwierzę. Sam fakt, że zdecydował się gromadzić żywność, wydaje się zaskakujący, jako że w Dolinie nie istnieje koncepcja jedzenia zakazanego, która uzasadniałaby chowanie czegoś przed wzrokiem innych i potajemne podjadanie; $\mathrm{w}$ jadłospisie dziecięcych postaci słodycze czy kawa zajmują w kwestii dostępności miejsce równe mięsu czy warzywom. Mimo że to Mama racjonuje żywność (otrzymuje się ją tylko podczas wspólnych posiłków, wycieczek lub specjalnych okazji, takich jak przybycie nowych gości), nie ukrywa jej, można na nią wręcz trafić na każdym kroku (Nikolajeva, 2000, 
s. 245). Nikt w rodzinie poza nią nie przygotowuje jednak niczego samodzielnie, więc Muminek musiał odejmować sobie od ust, żeby móc coś odłożyć na później. W dwóch zdaniach opisu: „[...] wlazł pod łóżko i wydobył spod niego swoją szufladę z zapasami. Było w niej kilka już stwardniałych naleśników, pół kanapki i jabłko" (Jansson, 1962/2017d, s. 68) można zatem dostrzec poważną zmianę w podejściu do kwestii żywienia:

- Nowy zwyczaj Muminka narodził się w czasie dobrobytu - jedzenia musi być tyle, żeby dało się je gromadzić, wydzielać z codziennych posiłków część do odłożenia i jednocześnie uniknąć niedoboru.

- Muminek nigdy wcześniej tego nie robił - postać gromadzi żywność sporadycznie i nieumiejętnie, jako że dotychczas nie była do tego zmuszona; stare naleśniki, jabłko i nadgryzioną kanapkę trudno nazwać odpowiednimi zapasami na czas głodu.

- Coś spowodowało narodzenie się tego zwyczaju - jeśli założymy, że kolejność tomów w serii odzwierciedla także chronologię wydarzeń, zgromadzenie zapasów następuje po Zimie Muminków, kiedy Muminek po raz pierwszy uświadamia sobie istnienie koncepcji głodu; jak zauważa Korczak (2016, s. 81), Dolina na samym początku serii zostaje przedstawiona jako miejsce idylliczne, jednak nie z powodu nadprzyrodzonych cech czy wyjątkowej przewidywalności, ale bogatej flory i obfitości jadalnych roślin, dlatego głód wydaje się nieobecny nawet jako idea. Dopiero podczas masowej imigracji leśnych stworzeń do domu rodziny Muminków okazuje się, jak wielki wpływ niedobór żywności ma nie tylko na funkcjonowanie organizmu, lecz także na hierarchię wartości (najważniejsze staje się zaspokojenie podstawowej potrzeby) i na stosunki społeczne (istoty swoim przybyciem niejako wymuszają na Muminku ugoszczenie siebie, gospodarz zaś, niezbyt zachwycony, robi wszystko, żeby zachować się przyzwoicie).

- Zwyczaj jest podtrzymywany - głód powoduje zachwianie poczucia bezpieczeństwa (Nikolajeva, 2000, s. 239), zwłaszcza wśród istot tak wiele uwagi poświęcających kwestiom żywienia. Muminki nie pozostawiają na zimę w domu żadnego łatwo psującego się jedzenia, jedynie takie, które łatwo przechowywać i ma długi termin przydatności, jak kruche pieczywo, kawa czy przetwory. Podczas katastrof takich jak powódź w jadłospisie dominuje natomiast żywność dobrze zabezpieczona i silnie przetworzona, np. konserwy czy czekolada. Tymczasem Muminek szykuje zapasy niewytrzymujące próby czasu, na dodatek poza zimą, jedyną porą do tej pory utożsamianą z brakiem pożywienia; to 
tak, jakby przeczuwał, że nawet czas nie-zimowy, który określa mianem „prawdziwego świata” (w domyśle: bezpiecznego i zrozumiałego), nagle może zostać dotknięty niedostatkiem.

Jak zauważają zarówno Maria Nikolajeva (2000, s. 245), jak i Hanna Dymel-Trzebiatowska (2019, s. 58-59), wraz z rozwojem sagi zmniejsza się ilość i różnorodność jedzenia pojawiającego się na jej kartach, przy czym zjawisko to zachodzi w dwóch porządkach, nieciągłym i ciągłym. Okazuje się, że zależność między żywnością a stanem środowiska wykracza poza tę pierwszą jednokierunkowość, w przypadku której „zaburzenie równowagi powoduje zaburzenie zwyczajów żywieniowych" - zmiany w jadłospisie w porządku ciągłym stają się sygnałem, że zmiana na gorsze dopiero nadchodzi (jak w przypadku Muminka i jego szuflady z zapasami).

\section{Ogień kuchenny, ogień ochronny}

Rytm czasu nieciągłego wyznaczają kolejne katastrofy i okresy spokoju pomiędzy nimi, które wiążą się ze zmianami stosunku ilości jedzenia przetworzonego i surowego. Według Claude’a Lévi-Straussa (1968/2010, s. 174) możliwość gotowania, czyli decydowania o tym, co się zje i w jakiej formie, przeciwstawiana zbieracko-łowieckiej przypadkowości jadłospisu, stanowi o rozdziale między stanem dzikości, zwierzęcości, a stanem społecznym; świadczy nie tylko o tym, czy osoba może decydować sama o swoim losie, lecz także wyznacza bezpieczną strefę o stabilnych warunkach, w których można odegnać ryzyko głodu. Osoba rozpalająca ogień kuchenny wyznacza ośrodek, wokół którego mogą gromadzić się inni.

W sadze o Muminkach symbolika ognia jako jednocześnie bezpiecznego i niszczącego pozwala przekonać się, kiedy mamy do czynienia z okresem spokoju, a kiedy z zaburzeniem równowagi; żywioł staje się także jednym z czynników kreujących tożsamość postaci. Dowiadujemy się o tym już w Małych trollach $i$ dużej powodzi (Jansson, 1945/2017c), kiedy poznajemy pochodzenie Muminków; jako istoty od zawsze mieszkające za piecami kaflowymi, czyli w miejscu zapewniającym ciepło i, co za tym idzie, postrzeganym jako źródło poczucia bezpieczeństwa, same dążą do jak największej stabilności. Ogień jest najważniejszym elementem otoczenia, który pozwala im poczuć się pewnie, i tym, który nie powinien zniknąć, żeby świat nie pogrążył się w chaosie. Po powodzi przedstawionej w tym tomie wielką otuchą napawa możliwość zjedzenia posiłku w domu latarnika, miejscu, w którym ogień jako źródło 
bezpieczeństwa nabiera szczególnego znaczenia; nie tylko pomaga on unikać zagrożenia statkom na morzu czy wskazuje drogę rozbitkom takim jak $\mathrm{Mu}$ minki, lecz także pozwala przetrwać w miejscu narażonym na ciągłe ścieranie się wody i ziemi. W duchu przywołanej wcześniej uwagi Gralewicz-Wolny (2019, s. 107) wybrzeże, na którym stoi latarnia, można nazwać obszarem ciągłej katastrofy, w związku z czym sam budynek wydaje się miejscem wyjątkowo pewnym, niezagrożonym przez nieprzerwanie niekorzystne warunki.

Do ognia trzeba jednak zostać zaproszonym; osoba, która go rozpala, dyktuje zasady panujące w najbliższym otoczeniu. Rozbitkowie mogą zjeść w latarni, bo zostaje im to zaproponowane, ale kiedy Muminek wprasza się na rytuał związany z rozpaleniem wielkiego ogniska w Zimie Muminków, traktowany jest jak intruz. Najwyraźniejszy przykład wyznaczania w ten sposób bezpiecznej przestrzeni i hierarchii widać w części Tatuś Muminka i morze - jako że ogień u Muminków najważniejszą rolę odgrywa w kuchni, kontrolująca go osoba nie tylko decyduje o tym, kiedy jedzenie zostaje wydane, lecz także wskazuje, gdzie warunki są na tyle stabilne, że można go w ogóle podtrzymać. Kiedy Tata chce zamanifestować swoją pozycję jako głowy rodziny, stara się przejąć kontrolę nad możliwością tworzenia bezpiecznej przestrzeni, decydowania, kiedy można być spokojnym, a kiedy trzeba mieć się na baczności:

- Żeby tylko nie było deszczu - powtórzyła Mama. Postawiła miedziany dzbanek obok ogniska i włożyła do wody kwiatki od Tatusia.

- A gdyby zaczęło padać - powiedziała - powinnam wyszorować jakieś garnki, żeby nałapać deszczówki. O ile są tu jakieś garnki...

- Przecież ja się będę zajmował wszelkimi rzeczami tego rodzaju! - zawołał Tatuś żałosnym głosem. - Poczekajcie tylko! Wszystko musi być zrobione po kolei. Nie możemy troszczyć się o jedzenie, o deszcz i inne takie drobiazgi, dopóki nie znajdę klucza! (Jansson, 1965/2014, s. 50).

Zmiany w stosunkach władzy, wyznaczane przez kontrolę nad ogniem i procesem przygotowywania żywności, ukazują, z którym okresem porządku nieciągłego mamy do czynienia. W okresach dobrobytu i spokoju Muminki żywią się głównie produktami ugotowanymi w niedługim czasie od ich zebrania, co zazwyczaj wiąże się z określonym ceremoniałem. Jedzenie przestaje być wtedy tylko czynnością: podczas gdy w życiu istot pozbawionych stabilności bardziej wyszukane potrawy wiążą się jedynie z pewnymi świętami (jak w przypadku tych stworzeń, które zdają się znać znaczenie wigilijnego jedzenia), dla Muminków różnorodne i skomplikowane potrawy stają się także środkiem do uczestniczenia w życiu społecznym i jego kształtowania, sygnalizowania statusu i kreowania własnego wizerunku (Barthes, 1961/2013, s. 28). 
Kiedy Topik i Topcia odnajdują jej torebkę, Mama decyduje się wydać przyjęcie na ich cześć - sama wyrabia ciasto na naleśniki w wannie i wyjmuje wielkie słoiki konfitur, a Tata robi ogromne ilości kruszonu. Fakt wydania przyjęcia, rozświetlenia doliny ogniem i przygotowania jedzenia w ilościach, które mają starczyć dla wszystkich, świadczy o szczodrości płynącej nie tylko z gościnności, lecz także dobrobytu, jako że nie wspomina się o tym, żeby ktokolwiek $z$ rodziny bał się, że nie starczy mu jedzenia na inne dni. Co prawda jest mowa o stołach uginających się pod ciężarem jedzenia przyniesionego także przez gości, ale w całej serii trudno znaleźć postać, która dysponowałaby zapasami w ilości umożliwiającej swobodne obdarowywanie innych; bardziej prawdopodobne, że życie wielu z nich wygląda jak sytuacja Włóczykija, gdy po konfrontacji z Dozorcą Parku musi zająć się gromadą dzieci i ma problemy z ich wykarmieniem. Kulminację sceny przyjęcia stanowi magiczne odesłanie jednego ze stołów, wszyscy zaś czują się na tyle bezpiecznie, że taki podarunek jest gestem całkowicie akceptowalnym.

Z tego typu scenami silnie kontrastują przedstawienia okresów trudnych, kiedy postaci nie mają ani tak łatwego dostępu do pożywienia, ani możliwości rozpalenia ognia. Czas katastrofy oznacza wejście w przestrzeń rządzoną przez siły przyrody, nieliczące się z mieszkańcami świata Muminków. Postaci trafiają wtedy do przestrzeni niesamowitości, której nie rozumieją, jako że ich rzeczywistość kształtują rytuały i poczucie kontroli nad wszystkim, co jest potrzebne

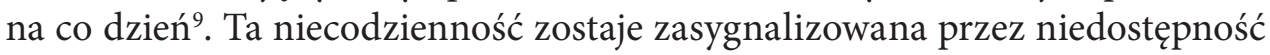
pożywienia - w Małych trollach i dużej powodzi jedyne, co udaje się znaleźć po potopie, to przemoczone bataty i garść fig (Jansson 1945/2017c, s. 44) oraz słodycze w domu starego pana (s. 20-21). W drugim przypadku mamy do czynienia z niesamowitością szczególnego rodzaju, jako że jedzenie to zdaje się nie należeć ani do kategorii dzikości, ani cywilizacji, jednocześnie istniejąc w obu sferach - słodycze powinny być zaliczone do jedzenia już ucywilizowanego, ale tu jednocześnie rosną, zachowują się jak rośliny. Lévi-Strauss (1968/2010, s. 272) zauważa, że gastronomiczna granica między naturą i kulturą jest przepuszczalna, przekracza ją m.in. koncepcja trucizny jako substancji naturalnej włączającej się w działalność kulturową. W tym przypadku mamy do czynienia z odwróceniem zależności, jako że substancja kulturowa zostaje włączona do natury, efekt jest jednak podobny - przekroczenie granicy przez

9 Do nielicznych wyjątków, które zdają się rozumieć wpływ zjawisk o skali globalnej na codzienne życie, należą Włóczykij, starający się żyć zgodnie z rytmem środowiska, oraz Too-tiki, zakładająca, że wszystko jest niezrozumiałe, co pozwala jej skupić się na obserwowaniu i podziwianiu świata, a nie próbach zdefiniowania jego natury. 
nieprzygotowane na to postaci okazuje się szkodliwe (Muminek i Ryjek nie wiedzą, że słodycze rosnące jak rośliny roślinami tak naprawdę nie są). Dom starego pana daje tylko złudzenie powrotu do dawnego porządku i wyraźnych kategorii, ale tak naprawdę go nie przynosi, dlatego zachowywanie się według starych zasad prowadzi do negatywnych konsekwencji. Z kolei kiedy tułacze doświadczają głodu już na zewnątrz, w przestrzeni zmienionych zasad, czekolada zabrana z magicznego ogrodu ratuje życie. Podczas katastrofy przestają działać dotychczasowe reguły, według których ma się wybór tylko między jedzeniem dzikim a ugotowanym (wspomniana czekolada jest spoza tej kategoryzacji). Poza tym to produkt, który bohaterowie dostają od Mamy, a zatem od osoby ustanawiającej przestrzeń bezpieczną, gotowej w kontrolowany sposób przekroczyć wspomnianą już granicę kategorii dzikości i natury oraz przeprowadzić przez nią także swoich podopiecznych.

\section{Składniki, przepisy, posiłki}

Zmiany w porządku ciągłym są zaś sygnalizowane przez wspomniane wcześniej ograniczenia w stałym jadłospisie postaci, kiedy zdobywanie pożywienia staje się coraz trudniejsze. Najlepiej widać to w kontekście przygód i wycieczek, na które co jakiś czas wypuszczają się niektórzy lub wszyscy członkowie rodziny. Mama stara się wtedy odtworzyć w obcym otoczeniu warunki domowe, zapewnić połączenie $\mathrm{z}$ bezpieczną przestrzenią niezależnie od dzielącej ich od niej realnej odległości. Jedzenie przygotowane w domu lub domowymi sposobami staje się bowiem symbolem przynależności, obietnicą, że ma się dokąd powrócić (Long, 2014, s. 241). Wiąże się to zresztą nie tylko z samym faktem zabezpieczenia przed głodem i spożywania produktów znanych z codziennego doświadczenia w karnawałowej, więc tymczasowej, przestrzeni niecodzienności; ogromne znaczenie ma też kwestia przyrządzania posiłków w określony sposób. Jansson, poświęcając w początkowych tomach serii wiele uwagi opisom żywności i szczegółom jej przygotowywania (jak chociażby w przypadku tortu hiszpańskiego), pokazuje, jak wielką rolę odgrywa w życiu Muminków nie tylko efekt gotowania, lecz także sam proces. Świadomość, że coś zostało przyrządzone w określony, znany sposób lub pochodzi z miejsca, które postrzegamy jako bezpieczne, staje się jego namiastką w nieprzyjaznym otoczeniu. Dlatego istotne okazuje się np. podpisywanie każdej paczki z daną potrawą, chyba nawet ważniejsze niż sam posiłek - kiedy w Lecie Muminków Migotka i Muminek postanawiają przenocować na drzewie podczas powodzi, a tymczasowy dom rodziny odpływa, pozostaje im jedynie kosz kanapek: 
W końcu Muminek wstał i machinalnie zdjął koszyk ze śniadaniem wiszący na gałęzi.

Był on pełen małych, porządnie zapakowanych w bibułkę paczuszek z kanapkami, po dwie każdego rodzaju. Ułożył je w szereg, ale nie miał ochoty jeść.

Nagle spostrzegł, że jego Mama napisała coś na paczuszkach. Napisy mówiły, co jest w której paczce. „Ser” albo „Tylko masło”, albo „Ta droga kiełbasa”, albo „Dzień dobry!”. Na ostatniej napisała: „Ta jest od Tatusia”. Była w niej puszka sardynek, którą Tatuś przechowywał od ubiegłej wiosny.

Od razu wszystko wydało mu się mniej niebezpieczne (Jansson, 1954/2017b, s. 70-71).

Istotny jest właśnie związek żywności z osobą Mamy i świadomość, że w jednej paczce jest puszka Taty, a w innej specjalna kiełbasa. Przez podkreślenie chociażby, że to "ta droga” wędlina, kanapka zostaje oplątana siecią znaczeń, które sprawiają, że staje się namiastką domu - do jej przygotowania wykorzystano produkt, który pochodzi ze znanego źródła (co jest wskazywane przez deiktyczne „ta”), a w dodatku nie jest tani, więc pewnie nie używa się go zbyt często, co sygnalizuje wyjątkowość sytuacji oraz relacji między przyrządzającym posiłek a jedzącym; mamy do czynienia z „tą” kiełbasą, co pokazuje, że między dwiema osobami istnieją wspólne doświadczenia, pozwalające na zamknięcie ich w eliptycznym określeniu. Kanapka odsyła więc do koncepcji bezpieczeństwa i powiązanych z nią przyzwyczajeń, które oddalają groźbę katastrofy jako czegoś wyrywającego z codziennej rutyny, zmiany niepewnej, strasznej przez swoją potencjalność (Jansson, 1978, s. 9).

To sprawia, że naręcza rzeczy zabieranych przez Mamę na wycieczki mają za zadanie zapewnić poczucie przygody (przez sugerowanie, że jej uczestnicy zawsze mają dokąd wrócić), a nie tułaczki, niebezpiecznej przez to, że nie ma wyraźnego końca. Jak zauważa Muminek w Zimie Muminków, kiedy jest u siebie w domu, nic mu nie może grozić. Przygody stają się inne wraz z upływem czasu, co obrazuje zmiany zachodzące w rodzinie pod wpływem przeistaczającego się środowiska. W czasach, kiedy żywności jest pod dostatkiem, Mama może sobie pozwolić na jej celebrowanie, w tym rozkładanie obrusu i zastawy. Obfitość jedzenia umożliwia także jego dobrowolne wyrzeczenie się - Muminek, kiedy wyrusza do obserwatorium z Ryjkiem i Włóczykijem, oświadcza, że będą jedli wprost z liści, odmawia także zabrania ze sobą patelni na naleśniki właśnie dlatego, że wierzy, iż po powrocie będzie mógł z powrotem korzystać z wygód (inaczej niż w przypadku groźby zniszczenia przez kometę, kiedy konieczne okazuje się chronienie dobytku, jako że mógłby nie przetrwać uderzenia). Patelnia na naleśniki ostatecznie pojawia się zresztą w ekwipunku podróżników, co wskazuje także na pewność, że po 
drodze uda się znaleźć potrzebne do ich przygotowania składniki i że w czasie dobrobytu, kiedy ma się zapewniony dostęp do wielu narzędzi, można pozwolić sobie na specjalizację niektórych $\mathrm{z}$ nich.

Z czasem zmienia się jednak i ilość uwagi poświęcanej posiłkom. Podczas gdy pierwszym, co robią inne istoty mieszkające w lesie po przebudzeniu się ze snu zimowego, są wiosenne porządki, rytualnym rozpoczęciem wiosny i pierwszą czynnością u rodziny tradycyjnie jest śniadanie. Żeby przetrwać zimę, czas katastrofy, a więc i odwróconych zasad, Muminki napełniają żołądki tym, czego przez resztę roku nie postrzega się jako pożywienia - igliwiem; powrót do „normalnego” (w rozumieniu Muminków jako istot nie-zimowych) świata wymaga jednak zjedzenia czegoś, co jest jedzeniem w porządku lata. Pierwsze wiosenne śniadanie staje się zatem równoważnikiem posiłku oferowanego Topikowi i Topci, towarzysząca mu intencja jest jasna: „Kończy się wasza wędrówka, znaleźliście bezpieczne miejsce”. Po wyjątkowo srogiej zimie, spowodowanej przelotem komety i wybuchem wulkanu, cała rodzina rozpierzcha się jednak w pogoni za innymi sprawami, nie ma słowa o śniadaniu. Nie jest to zresztą efektem opróżnienia spiżarni, bo wtedy rozpoczęłyby się poszukiwania czegoś do zjedzenia po tak długim okresie snu. Reakcja na przyjście akurat tej wiosny zwiastuje radykalną zmianę w sposobie myślenia.

W Tatusiu Muminka i morzu nie ma już mowy o składzie posiłków, zaledwie się o nich wspomina. Rodzina zabiera ze sobą na wyspę, na którą mają przeprowadzić się na dłużej (o ile nie na zawsze), jedynie produkty do długiego przechowywania, np. kawę i konserwy; w tekście nie znajdziemy wzmianki o tym, czy w łodzi znalazły się jakiekolwiek warzywa czy sadzonki. Tę zaskakującą decyzję - Mama chciała przecież założyć ogródek warzywny - trudno uzasadnić roztrzepaniem Taty, który, bądź co bądź, chce zadbać o przetrwanie rodziny, pomimo kontrowersyjnych decyzji podejmowanych w tym tomie. Najbardziej prawdopodobne, że Muminkom po prostu zabrakło żywności, w którą można by się zaopatrzyć, co widać w ostatniej przedstawionej w serii wycieczce rodziny. Mama nie stara się już odtworzyć domowych zwyczajów, pojawiają się jedynie kawa i chleb z masłem; w porównaniu z uprzednią szczegółowością i pietyzmem Jansson w przedstawianiu jadłospisu Muminków ten brak jawi się jako znaczący. Zasadne wydaje się założenie, że chociaż Mama robi, co może, żeby przypomnieć swojej rodzinie i sobie miejsce, za którym tęskni, klimat uległ już takiej zmianie, że nie ma nośnika, który umożliwiłby odświeżenie pamięci. Możliwe jest także, że historia Muminków zatoczyła z punktu widzenia Mamy koło i wróciła do czasu tułaczki, podczas której powrót do domu staje się niemożliwy. Dlatego wycieczka staje się jedynie oderwaniem od 
codzienności na wyspie, a nie przygodą, która miałaby swoje szczęśliwe zakończenie wśród obfitości jedzenia i związanych z nim zwyczajów zapewniających poczucie bezpieczeństwa.

Sceną, która najlepiej obrazuje różnorodność podejścia do zjawisk pozostających poza kontrolą mieszkańców i mieszkanek świata Jansson, jest zebranie zwołane przez Migotka w Komecie nad Dolina Muminków jeszcze przed przybyciem całej grupy do Doliny. W obliczu sprawy nienależącej do codziennego doświadczenia, ale coraz mocniej w nie ingerującej, niemal każdy stara się zastosować strategię myślenia nieciągłego i sprowadzić problem do zrozumiałych kategorii i form:

Wszyscy usiedli.

- Mianuję siebie przewodniczącym i sekretarzem - mówił dalej Migotek. - Czy są jakieś inne propozycje?

Nikt nie miał innych propozycji, więc Migotek stuknął trzy razy długopisem w ziemię.

- Co to było? Czerwona mrówka? - spytała jego siostra.

- Cicho, przeszkadzasz w zebraniu - syknął Migotek. - Co my właściwie wiemy? No tak. To, że zderzenie nastąpi w piątek siódmego sierpnia o godzinie ósmej czterdzieści dwie wieczorem. Może cztery sekundy później.

- Czerwona mrówka? - szepnął Muminek w zadumie. Siedział, patrząc na grzywkę Panny Migotki. Mama nie nosiła grzywki i pierwszy raz w życiu widział takie uczesanie.

- Dlaczego nikt nigdy nie chce słuchać tego, co ja mówię? - spytał zrozpaczony Migotek.

- Tego nie wiem - odparł Ryjek. - Czy zawsze tak było?

- Przestańcie wreszcie gadać i posłuchajcie tego, co Migotek ma do powiedzenia - rzekł Włóczykij. - On chce, żebyśmy się zastanowili, czy jest jakaś szansa ocalenia.

- Idziemy przecież do domu - powiedział Muminek. - I wy chyba idziecie $\mathrm{z}$ nami?

- Tą sprawą możemy zająć się bardziej wnikliwie na następnym zebraniu - odrzekł Migotek.

[...]

- Czy naprawdę nie możecie trzymać się tematu? - przerwał im Migotek i znów stuknął długopisem. - Czy, po pierwsze, możemy przypuścić, że zdążymy do jakiejś doliny przed kometą, i czy, po drugie, większe jest prawdopodobieństwo uratowania się tam niż gdzie indziej?

- Jak dotąd, udawało się nam - powiedział Ryjek.

- Mamusia na pewno to załatwi - orzekł Muminek. - Zobaczysz, jaką mamy piękną grotę (Jansson, 1968/2016, s. 90-92). 
Niemożliwa okazuje się jakakolwiek pełna analiza sytuacji, zamknięcie w spójną narrację zarówno samego zjawiska, jak i jego przyczyn oraz skutków. Postaci starają się nie zauważać niebezpieczeństwa; stosują stare, niepasujące do nowej sytuacji pojęcia i sposób postrzegania świata (Mama raczej nie powstrzyma komety) lub podejmują się próby zrozumienia dla samego próbowania, rozsmakowując się w formie (Migotka pociągają wszelkiego rodzaju biurokracja i konwenanse). Jedynie Włóczykij zdaje się pojmować powagę zagrożenia, ale - podobnie jak Too-tiki w przypadku zorzy polarnej - nie dąży do zrozumienia przez zamknięcie problemu w słowach; kometa, tak jak zorza czy zmiany klimatu, z jego perspektywy po prostu się zdarza i trzeba się do tego dostosować, a nie starać się wywrzeć wpływ na bieg wydarzeń.

\section{Zakończenie}

Zarówno pojedyncze czynniki wpływające na klimat i sygnalizujące jego zmianę, jak i sam długotrwały proces wymykają się próbie opowiedzenia za pośrednictwem nieciągłej narracji, dzielenia jej na fragmenty. Zrozumienie zjawiska opartego na ciągłości, na wzajemnym wpływie wielu różnych czynników, okazuje się niewykonalne przy założeniu, że pojęcie wielkiego problemu jest sumą odpowiedzi na mniejsze pytania. W serii o Muminkach, czytanej przez pryzmat studiów nad jedzeniem i nad zmianami klimatu, udaje się uchwycić istotę takiego typu narracji, który pozwala opowiedzieć o procesie rozłożonym w czasie, opartym na ciągłej obserwacji subtelnych, kumulujących się zmian. Mimo że skala zjawiska może wydawać się na tyle wielka, że staje się ono niemożliwe do opowiedzenia, a zatem także do przedyskutowania, forma sagi i skupienie się na kwestiach bliskich postaciom pozwalają dostrzec, że zmiana klimatu nie sprowadza się do pojedynczych wydarzeń czy też, przeciwnie, do abstrakcyjnych liczb i analiz. Zmiany klimatu nabierają charakteru dwukierunkowej relacji, w której środowisko znacząco wpływa na zwyczaje na poziomie lokalnym, na potrzeby i sposób życia, także w sposób ciągły i subtelny. Opowieść o długotrwałym procesie może zatem powstać bez konieczności tworzenia nowych form narracji, a coś, co z pozoru jest nieuchwytne, można obserwować w dużym przedziale czasu z perspektywy bliskiej postaciom. 


\section{Bibliografia}

Barthes, R. (2013). Toward a psychosociology of contemporary food consumption. W: C. Counihan, P. Van Esterik (red.), Food and culture: A reader (s. 21-30). Routledge. (wyd. oryg. 1961).

Behringer, W. (2010). A cultural history of climate (P. Camiller, tłum.). Wiley. (wyd. oryg. 2007).

Ćwiek-Rogalska, K. (2013). „Wielu miało katar, a niektórym było tęskno do domu”. Powieści Tove Jansson o Muminkach jako narracja o przesiedleniach. Humanistyka XXI wieku. Rocznik Doktorantów Wydziału Polonistyki Uniwersytetu Warszawskiego, 1(4), 34-40.

Dymel-Trzebiatowska, H. (2019). Filozoficzne i translatologiczne wędrówki po Dolinie Muminków. Wydawnictwo UG.

Ghosh, A. (2016). The great derangement: Climate change and the unthinkable. University of Chicago Press.

Gralewicz-Wolny, I. (2019). Muminki - między wodą a ziemią. W: I. Gralewicz-Wolny, B. Mytych-Forajter, Po pierwsze. O literaturze dla dzieci (i nie tylko) (s. 105-115). Wydawnictwo UJ.

Jansson, T. (1978). Bezpieczeństwo i strach w książkach dla dzieci (T. Chłapowska, tłum.). Literatura na Świecie, 6, s. 6-9.

Jansson, T. (2014). Tatuś Muminka i morze (T. Chłapowska, tłum.). Nasza Księgarnia. (wyd. oryg. 1965).

Jansson, T. (2016). Kometa nad Doliną Muminków (T. Chłapowska, tłum.). Nasza Księgarnia. (wyd. oryg. 1968).

Jansson, T. (2017a). Dolina Muminków w listopadzie (T. Chłapowska, tłum.). Nasza Księgarnia. (wyd. oryg. 1970).

Jansson, T. (2017b). Lato Muminków (I. Szuch-Wyszomirska, tłum.). Nasza Księgarnia. (wyd. oryg. 1954).

Jansson, T. (2017c). Małe trolle i duża powódź (T. Chłapowska, tłum.). Nasza Księgarnia. (wyd. oryg. 1945).

Jansson, T. (2017d). Opowiadania z Doliny Muminków (I. Szuch-Wyszomirska, tłum.). Nasza Księgarnia. (wyd. oryg. 1962).

Jansson, T. (2017e). Zima Muminków (I. Szuch-Wyszomirska, tłum.). Nasza Księgarnia. (wyd. oryg. 1957).

Jansson, T. (2018). Pamiętniki Tatusia Muminka (T. Chłapowska, tłum.). Nasza Księgarnia. (wyd. oryg. 1950).

Korczak, A. M. (2016). Zgoda na siebie. Przełamywanie imperatywu socjalizacji w cyklu o Muminkach autorstwa Tove Jansson. Wydawnictwo SBP.

Lanchester, J. (2019, 25 marca). How the Little Ice Age changed history. The New Yorker. Pobrane 21 grudnia $2020 \mathrm{z}$ : https://www.newyorker.com/magazine/2019/04/01/ how-the-little-ice-age-changed-history. 
Lévi-Strauss, C. (2010). Surowe i gotowane (M. Falski, tłum.). Aletheia. (wyd. oryg. 1968).

Long, R. A. (2014). Food, love and childhood: Surviving and thriving in the Deepwoods. W: B. Carrington, J. Harding (red.), Feast or famine? Food and children's literature (s. 240-262). Cambridge Scholars.

Ługowska, J. (2012). „Przyjdzie kometa, machnie ogonem i wszystko diabli wezmą”. Od ludowych wyobrażeń do Tove Jansson. Colloquia Anthropologica et Communicativa, 5, 441-455.

Macfarlane, R. (2005, 24 września). The burning question. The Guardian. Pobrane 21 grudnia 2020 z: https:/www.theguardian.com/books/2005/sep/24/featuresreviews.guardianreview29.

Mann, M. E. (2002). Little Ice Age. W: M. C. McCraken, J. S. Perry (red.), Encyclopedia of global environmental change, volume 1 - the Earth system: Physical and chemical dimensions of global environmental change (s. 504-509). Wiley.

McKibben, B. (2005, 22 kwietnia). What the warming world needs now is art, sweet art. Grist. Pobrane 21 grudnia 2020 z: https://grist.org/article/mckibben-imagine/.

Nikolajeva, M. (2000). From mythic to linear: Time in children's literature. Rowman \& Littlefield.

Pessel, W. K. (2019). Uporczywe kartografie i mapy z Doliny Muminków. Prace i Studia Geograficzne, 64(4), 53-65.

Wallace-Wells D. (2019). Ziemia nie do życia. Nasza planeta po globalnym ociepleniu (J. Spólny, tłum.). Zysk i S-ka. 